\title{
Professional Teachers' Perspective toward an Effective Teaching Technique: A Case Study
}

\author{
Nurus Sobakh (Corresponding Author) \\ STKIP PGRI Pasuruan, Indonesia \\ E-mail: zobex.stkippgripas@gmail.com
}

Received: October 7, 2017 Accepted: November 17, 2017 Published: November 28, 2017

doi:10.5296/ijld.v7i4.12112ＵRL: https://doi.org/10.5296/ijld.v7i4.12112

\begin{abstract}
This study aims to describe the teachers' perspective about the effective teaching technique to teach young leaner in Pasuruan Indonesia. The research design was qualitative case study design. This study tried to investigate the effective teaching technique to teach young learner. The teaching process had been implemented by the teachers. In this study, the teachers would describe their teaching learning process in their classroom. The subject of this study was the professional teachers' of junior high school in SMPN 1 Gempol and SMPN 1 Beji. The classroom was chosen based on the teacher's approval and suggestion. The professional teachers were the teachers who had legal certificate as the educator from the government and who had taught more than ten years. The researcher collected the data from the observation sheets, field note, and teachers' interview. The researcher found that the teachers ordered the steps of teaching technique from the beginning until the end effectively and systematically. The teachers had fulfilled the criteria of professional teacher. They had a better classroom management skill and ordered various kinds of teaching activities and practices in their classroom splendidly.
\end{abstract}

Keywords: professional teacher, effective teaching technique, young learner 


\section{Introduction}

Teaching is a way of transmitting knowledge information from the teacher to the students by using an effective teaching technique and learning strategy. Yamin (2007) suggested that the teachers should improve their potential to discover the proper teaching technique to create innovative, inspired, effective, and pleasant teaching learning atmosphere. Teachers should not only seize the teaching material, but also should have extensive knowledge of the technique which are most effective for teaching different level of students' skill. The teaching technique is leading the students' learning skill ability. Moreover, as stated by Brown (2004), teacher should choose techniques which depend on the specific purpose of the learning process.

According to E. Mulyasa (2003:53) educators must have academic qualifications and competence as agents of learning, and have the ability to achieve national education goals. While, teachers and lecturers are professional educators with the primary task of educating, teaching, guiding, directing, training, assessing and evaluating the students through formal primary education and secondary education Professional teacher is a teacher who has received formal recognition by the applicable provisions, either in the office or formal educational background. This recognition is expressed in the form of a decree, diplomas, and certificates which is concern to the qualifications or competence, Djam'an et al. (2010)

Thus, professional teacher should have the following competencies as stated by Dean, G (2013), first is professional competence, it means teachers should have a broad knowledge of the subject matter that will be taught. Teachers should have knowledge of theoretical concepts, able to choose the appropriate method and able to use various methods in the learning process. Besides that, teacher should have personal competence, so they can be a model. In addition, teachers should have social competence, it means she or he shows the ability of social communication with students and the other people. Moreover, teacher should have pedagogic competence. Pedagogical competence is the ability of teachers to manage the teaching learning process.

In teaching learning process technique of teaching is the important thing. The ability to use appropriate technique of teaching will be influence the students' achievement. Brown (2001: 15-16) Technique is refers to variety of exercises, activities, or task used in the classroom for realizing the lesson. To teach effectively, the teachers should use appropriate teaching technique. Because, the use of technique make the teaching learning process more effective than those which do not use technique. As stated by Yazar (2013) "using appropriate technique make the lessons more effective”.

Susanti (2015) argues that a lot of teachers were good in conducting teaching learning process. In addition, Pandika (2016) says that teachers should give various technique of teaching to make the students more enthusiastic in teaching learning process. Although some of the teachers were good in teaching, yet some of the students found the difficulties in the learning process and uninterested. Sometimes, the students did not understand what have they learn in the fact. It is proven based on the researcher observation on some students did not understand about the information and unmotivated to read. When the researcher gave 
some questions related to the texts for some students, the students seem difficult to answer the questions given were about the materials given, how many text that the students have learned or give responses, the purpose of the material. From some questions mentioned, there was only one question which could be answered by the students. Yet, from ten students, there was only one of them who could mention one of the text types but he cannot mention the information of material.

In addition, as quoted from Nanang (2016), there are two factors that make students unmotivated. The first factor is internal factor and the second factor is external factor. One of the internal factor is uninteresting material presented to the students. The external factor may come from the teacher who cannot manage the class with various ways of teaching very well. Although the technique of teaching also influence the students' emotional state. In the fact, teachers think that they could teach the materials optimally. In contrast, there were some students' claimed that they got difficulties in mastering skill. Based on the reasons mentioned, the researcher intends to find the effective technique of teaching technique for junior high school level. It is expected by conducting this research, there will be many suggestions for implementing best technique in teaching in order to enhance the quality of teaching in Pasuruan. In this research, the researcher only focuses on professional teachers' opinion at junior high school level. The researcher only takes professional teachers as the subjects of this research because they are recognized as teachers who have good competence which is proven with legal certificate from the government required by Legislation (2005) in line with the reasons and goals of this research. In this part, the research will explain the objective of the research are to know Teachers' perspective about teaching in pasuruan and to investigate the effective technique in teaching technique for junior high school level.

\section{Research Methodology}

The research design of this study was to find out the most effective of teaching technique which were implemented by the teacher and described why she or he use it in the teaching learning process. The researcher used case study as the research design. Creswell (2010: 20) says that case study is an in-depth exploration of bounded system (e.g., activity, event, process, or individual) based on extensive data collection.According to Lambert (2012) the goal of qualitative descriptive research is comprehensive summarization in everyday terms of specific events experienced by individual or group. Therefore, the researcher describe the whole process of the teaching and learning process

The subject of this study was the professional teachers' of junior high school in SMPN 1 Gempol and SMPN 1 Beji. The class was chosen based on the teacher's suggestion. Professional teachers were teachers who have get legal certificate as the educator from the government or teachers who have taught more than ten years. In this research the criteria of professional teachers not only based on the certificate but also based on teacher's experience in teaching. The subjects of the research are the professional teachers. It refers to teachers who are already certified officially. Also based on the period of teacher's certification, qualification of their study program and their participate in teacher's training. Moreover, they are the teachers who have taught more than ten years. 
Observation sheet is used to help the researcher to collect the data about teaching technique of the teachers in the class. Leedy and Ormrod (2001) says that observation instrument can be form as the checklist form or ratio scale The instrument is aims to find out the real activities and situation done by the teacher and the students in the classroom. The researcher collected the data by observing the process of teaching and learning process in the class. For the first observation was done by teacher A on July $20^{\text {th }}, 2017$. The second observation was done by teacher B on July $21^{\text {rd }}$, 2017. The first observation was done in 80 minutes for the eight graders of SMPN 1 Gempol. The second observation was done in 90 minutes for seventh graders of SMPN 1 Beji.

The interview will be used to collect the data from the teachers in order to support this research. As stated by Wilkinson et al (2003:43) interview guide is design for the teacher before the research was conducted. But the researcher used the interview guide after teaching learning process was done. It aims to get information. In the interview guide the researcher ask some questions about problem in teaching process the technique that used in pre-activities, whilst-activities, and post activities. The researcher also adds some questions about teacher's and student's achievement while academic or non-academic achievement to emphasize that those are favorite school. The interview was done after teaching learning process. The researcher made the agreement with the teacher to have interview after the teaching learning process. This interview aimed to verify the data form observation to the teacher's perspective. The result of this interview will be transcript in to print out data form.

In the process of data analysis, the researcher used the code based on the teacher's name, the school's name and the item of interview number one to differentiate between the participant of the research. For example SY from SMPN 1 Gempol and the duration of teaching is 20 years. The second example is S from SMPN 1 Beji and the duration of teaching is 21 years. So, the codes are NL/SMPG 20 and S/SMPB 21. Then next process was collecting the data from the observation, field note, interview, and recorder. Then, the next step was the data reduction where the data were selected into relevant and irrelevant data. The relevant data would be analyzed and arranged into systematic order. For the irrelevant data which could not support the study would be eliminated. The next steps was identifying, classifying, arranging, and clarifying the data. The identification was done by recognizing and checking the data. After that, the data were classified by selecting the data (Creswell, 2009)

\section{Finding and Discussion}

The researcher found that the teacher (NL/SMPG 20) used three phase technique to achieved his teaching and learning objective because it able to make the students understand more about the lesson. Furthermore, the students could learn from each other and it could reduce the wasting time. The teacher said that technique that he used in the class had some purposes that were made the students easy to understand the lesson, to know the students social capability in the team work. Moreover, trained the students to express their opinion and share with others. The teacher made group- learning to reach the goal of teaching. Group-learning also made the students reduce their selfishness. It could increase student's critical thinking. The teacher divided the activity into three phases those were pre-activity, main activity, and 
post activity.

In the pre-activity the teacher start the lesson by prayed together. Then, he said greeting to her students. Before he explained the lessons, he introduced the theme that would be learned. Then, the teacher activated the student's prior knowledge about the lesson with some questions. The teacher explained the purposed of learning, the generic structure of the text, the language feature and purpose of the text to make the students interested.

The teacher (S/SMPB 21) applied jigsaw technique for the students on seventh grader. He argued that cooperative learning strategy (jigsaw) could build student's skill and reduce their selfishness. He stated that strategy was important to transfer the material. That was why he should choose the appropriate technique to be implemented in his class. He often used jigsaw technique when he taught because it had some advantages for the student's social skill and student's cognitive skill.

The advantages of jigsaw technique were the teacher was not the sole provider of knowledge because every student became an expert and every student could teach to each other what they have learned. Moreover, jigsaw was efficient ways to learn. It means that the students did not need to read a long text, even the story composed by long text because in jigsaw every student has own piece task. In the jigsaw technique the students were claimed to responsible of their own task and they should be able to explain and share what they have read to the other in order to complete the task. In addition, students were active participant in the learning process, in jigsaw technique each student participate and become an essential part in classroom because they should responsible to do their task. Furthermore, jigsaw technique could built interpersonal and interactive student's skills, jigsaw was a cooperating teaching method where the student work in a group, so it would bring the student to make a relation, cooperate, and share each other for finishing their task.

The teacher A and B used different technique to handle the class. One of them used Three Phase Technique and the other one used jigsaw technique. Both of the techniques that they used had the advantages and the disadvantages. The researcher could conclude that the advantages of the technique that mentioned were the same. It aimed to increase student's skill and student's achievement in teaching lesson. Based on the researcher observation, the researcher found that three phase technique more effective than the jigsaw technique to implement in the teaching class. Because, the students could achieve the materials completely. In contrast, in the jigsaw technique the students could not achieve the materials completely. It occurs when the students left one of the steps in the jigsaw technique and they cannot handle the learning materials or the teacher did not give clear explanation about jigsaw technique. Jigsaw technique has the same basic principle as puzzle game. So, if the pieces of the puzzle was lose, the puzzle cannot be completed. Based on the observation of the teacher $\mathrm{B}$, the researcher found that the teacher explained the steps of jigsaw technique clearly. In the fact, the students could not apply the step of jigsaw technique very well because there were some students who were unable to handle their teaching material in jigsaw activity. They could not manage the time very well. It was shown by the group of the students who could not finish the explanation of the materials. It occurs because they could not manage the time. As 
mentioned by Sabbah (2016:453) jigsaw strategy is a cooperative learning technique that encourages listening, engagement, interaction, teaching, and cooperation by giving each member of the group an essential part to play in the academic activity. The strategy involves breaking the classroom into small groups of four to six students. Each group is responsible for a specific piece of knowledge that will be discussed with other classmates.

As mentioned in the findings that teacher A (NL/SMPG 20) and teacher B (S/SMPB 21) gave various reasons to implement the technique. Based on the result of the interview the researcher found that both of the teachers stated that the used of technique in teaching process was important. Because it could help the teacher organize the activity in the class. In addition, used technique could minimize the problem that would appear in the teaching process. Moreover, the technique able to make the students easy to learn. As stated by Hidayat et al, (2000:1) technique is varieties of activity that used to reach the purpose of learning.

\section{Conclusion}

The researcher concluded that the effective teaching technique to teach young learner were jigsaw and three phase teaching technique. They could facilitate the teacher to transmit the knowledge and the information of learning material which was needed by the student effectively and they could improve student's cognitive skill, affective skill and social skill from the team work. The students were interested to understand the learning material. In understanding information from learning material sources, the students were enthusiastic. Although, every teacher employed different teaching technique but they have the equal function. It aimed to make the students easy to learn and reach the goal of teaching process. In this study, the researcher only focused on the professional teacher's perspective toward the effective teaching technique to teach young learner especially junior high school in Pasuruan.

\section{References}

Alderson, J. C. (2000). Assessing Reading. Cambridge University Press. https://doi.org/10.1017/CBO9780511732935

Brown, H. D. (2001). Teaching by Principles; an Interactive Approach to Language Pedagogy (2nd ed.). New York: Longman.

Brown, H. D. (2004). Language Assessment: Principles and Classroom Practices. NewYork: Pearson Education.

Creswell, J. W. (2009). Research Design: Qualitative, Quantitative, and Mixed Methods Approaches (3rd ed.). Los Angeles: Sage Publications, Inc.

Creswell, J. W. (2010). Qualitative Enquiry and Research Design: Choosing Among Five Approaches. Thousand Oaks, CA: Sage Publications.

Dean, G. (2013). Teaching Reading in the Secondary Schools (2nd ed.). London: David Fulton.

Djam'an, et al. (2010). Profesi Keguruan. Jakarta: Universitas Terbuka. 


\section{Macrothink}

International Journal of Learning and Development

ISSN 2164-4063 2017, Vol. 7, No. 4

Hidayat, Kosadi, dkk. (2000). Teaching And Learning in Indonesia. Putra Abardin.

Lambert, V. (2012). Qualitative Descriptive Research an acceptable design. PasificRim International Journal of Nursing Research, 16(4).

Mulyasa, E. (2008). Standard of Competences and Teachers' Certificate. Bandung: PT Remaja Rosdakarya.

Nanang, B. S. (2016). Some Causes of Disobidient Student. Retrieved from http://www.grahabelajar.com

Pandika, I. (2016). A Study on Teaching Reading Narrative Text at the Eight Grade of SMP NEGERI 10 Pasuruan. Unpublished S1 Thesis. Pasuruan: STKIP PGRI Pasuruan. Accessed on $5^{\text {th }}$ April 2017.

Sabbah, S. S. (2016). The Effect of Jigsaw Strategy on ESL Students'. Arab World English Journal (AWEJ) 7(1), 453. https://dx.doi.org/10.24093/awej/vol7no1.27.

Susanti, R. (2015). A Study on Teaching Reading for the Second Grade Students at SMPN 1 Beji. Unpublished S1 Thesis. Pasuruan: STKIP PGRI Pasuruan.

Yamin, M. (2007). Students Learning. Jakarta: Gaung Persada Press Jakarta.

Yazar, U. (2013). Teaching Reading to EFL Students to Make Them Better Readers. Journal of Studies in Education. https://doi.org/10.5296/jse.v3i3.3895

\section{Copyright Disclaimer}

Copyright for this article is retained by the author(s), with first publication rights granted to the journal.

This is an open-access article distributed under the terms and conditions of the Creative Commons Attribution license (http://creativecommons.org/licenses/by/4.0/). 